\title{
LATIN AMERICAN AND BRAZILIAN CONSTITUTIONALISM: THE RIGHTS OF THE TRADITIONAL PEOPLES
}

Monique Falcão

PhD Candidate and Master at Law at Universidade do Estado do Rio de Janeiro, Professor at Universidade Santa Ursula, Brazil.

mqfalcao@gmail.com

Ricardo Falbo

Post-Doctoral Researcher at Université Panthéon-Assas, PARIS 2. Professor at Universidade do Estado do Rio de Janeiro, Brazil.

neryfalbo@gmail.com

Received: 2015-01-03. Accepted: 2016-02-05.

\begin{abstract}
This article presents the XXI's constitutionalism as the doctrine of the constitutional law hich supposes to be a theoretical framework able to assure the interpretation of the political and social processes from which political constitutions emerge. Thus, the 88's Brazilian Constitution proceeded to the recognition of the fundamental rights and norms regarding theprotection of minority rights. The purpose of this work is to investigate if this supposed innovative characteristic of the 88 's Brazilian Constitution is able or not to set historicalconstitutionalism as the continuity or maintenance of the conservative processes of the politicaland social status quo in the country. This article intends to discuss the nature of constitutional changes and the impacts of these changes on the development of constitutionalism in Brazil by analyzing the extent to which political, social, and cultural latin-american processes influenced changes in Brazilian constitutionalism.
\end{abstract}

Keywords: Constitutionalism - Substantialism - Procedimentalism Fundamental rights - Minorities 


\section{INTRODUCTION}

This work starts from the general hypothesis according to which the theoretical history of constitutionalism is constructed based on the empirical and historical context of constitutions and that it defines historicism as a perspective for the study of constitutions and different forms of constitutionalism. Thus, the historical characteristics of particular constitutions in specific contexts should also define constitutionalism in a particular way on its particular historical trajectory. Conservative or innovative character of specific constitutions would set constitutionalism according to their continuities and ruptures and translate the nature of the social and historical contexts of those constitutions.

However, the relationship between constitutionalism and constitution according to the historical perspective and their contexts has not been doctrinally established by the jurists in the framework of constitutional law. And this is not because the basic unit of analysis of constitutions has been defined by normative categories that these constitutions do enshrine and express, but because such categories have not been understood according to their historical contexts and their political and / or social processes. At most, these contexts and processes appear as rhetorical constructions in the doctrinal field of constitutional law.

The absence of real history leads the Brazilian constitutionalism to produce a view of itself as a set of doctrinal constructions deduced in a mechanical way from constitutional norms. It is precisely the split between the "real constitutionalism", regarding the relationship between historical and social contexts in the XXI century and that define the crisis of Western modernity , and the "doctrinal constitutionalism", as the detailed studies of the Brazilian Constitution of 1988 according to epistemological reflection of theoretical and methodological nature, that has produced the reduction of the Brazilian constitutionalism to the formal analysis of the constitutional norms and prevented the understanding of what has been defined as the "innovation" that characterizes both the said constitution as the constitutionalism. Out of history "it is not possible the novelty, the dialectical leap that lets you step from one level of achievement to another, the emergence of new forms of existence." (BONDY, 1982: 130). This is a set of ideas that defines the specific hypothesis of this study. Brazilian constitutionalism does not seem to consider that constitutionalism is built as a doctrine of constitutional law or the constitution according to theoretical and methodological requirement that implies both the definition of constitution and a theoretical model to ensure the interpretation of the context or the political and / or social context in which the phenomenon "constitution" (WOLKMER, 1989:13-15) happens. 
And this context, in the XXI century, does not only show the advance of social and economic globalization, but also that of the globalization of law. The various dimensions of globalization processes have produced different ways of confronting investigations concerning elaborations of constitutions, studies of constitutional rights and different constitutionalisms. Without such a view, the study of Brazilian Constitution of 1988 and the Constitutionalism from this period will always be conducted independently of Latin American constitutions and constitutionalism itself in Latin America. The absence of epistemological reflection on it institutionalizes Brazilian constitutionalism as the study of constitutions as a natural fact, as the study that does not guarantee understanding the nature of the changes of the constitutions and constitutionalism as to the senses of its historical trajectory in Brazil or in Latin America. The practical objective of this work is to characterize and feature the reified and reifying dimensions of this framework in the field of constitutional argumentation.

The descriptive methodology of this kind of investigation shifts the condition of possibility of thinking the trajectory of constitutionalism in Brazil from the traditional and positivist field of the jurists to the field of historians by strengthening modern and artificial separation as to the field of study based on the specialization of tasks. In the field of the constitutionalists, the history of the constitutions and constitutionalism would only be conceived as an expression of unique and unquestionable facts, according to a linear and homogeneous time, as true foundational myths. Another view of history would only be possible in the field of the historians, and outside the law. On the one hand, the positivist methodology has legitimized the use of foreign doctrines and theories in order to explain changes in the Brazilian constitutional right, but they have remained unexplained. On the other hand, that methodology has been grounded in the XXI century on classic ruptures introduced by Western modernity, which is in crisis since the twentieth century, and it has not guaranteed the questioning neither of the originality nor of the singularity of the Brazilian constitutionalism.

This is a set of ideas that allows specifically demarcating the field of argumentation in this work and defining one of its major theoretical purposes: to characterize the current stage of constitutionalism in Brazil as to the recognition of fundamental rights in the Brazilian Constitution of 1988 and the rules destined for minority rights. It is also this set of ideas and the hypotheses above that legitimate the problematic that this paper seeks to address with respect to the following questions: In the study of Brazilian constitutional norms, the Brazilian constitutionalism has revealed paradigmatic shift regarding the importation of European and North American theories and ideas so as to recognize the political and social, historical and cultural influence 
from the Brazilian or Latin American context in the production and understanding of the Brazilian Constitution of 1988 as well as in the understanding of the trajectory of constitutionalism? If not, what factors or processes may explain, in the works of constitutionalists, the absence of that influence in explaining the emergence of the Brazilian constitution of 1988 and especially in the Brazilian constitutionalism?

The condition for the formulation of questions and hypotheses in this work reveals the condition that is absent in the works of Brazilian constitutionalists in general, namely: the questioning of the crisis of modernity with reference to Brazil and Latin America. "First of all we must destroy that logic by which our societies are hopelessly outside the process of modernity and that their modernity can only be true deformation and degradation" (Martin-Barbero, 2006: 23).

From a theoretical and methodological perspective, this work is based on the presentation, characterization and definition of ideas and categories of thought by two Brazilian constitutionalists and professors of constitutional law: Daniel Sarmento $(2006,2009)$ and Luis Roberto Barroso (2004).

Without assigning them the status of national representatives of theoretical and doctrinal trends of constitutionalism followed in Brazil, those constitutionalists were chosen as representatives of constitutional doctrines underlying the training of students of the faculty of law of the State University of Rio de Janeiro. The faculty in question is regarded as a national reference in Rio de Janeiro and Brazil. And this is the school where those constitutionalists graduated. The relationship articulating "constitution", as a particular and concrete fact, and "constitutionalism", as a universal doctrine, will be investigated through some fragments of works of those writers on the Brazilian Constitution of 1988.

This choice is justified by the argument that there are contradictions between professional practice and discourse in the Brazilian constitutional doctrinal field since the promulgation of the Brazilian constitution. Sarmento has been a member of the Federal Public Ministry, where he has been part of the committee for the defense of collective rights, and Barroso has been a member of the Federal Court of Justice. The most significant contradiction lies in the following fact: both constitutionalists seek to solve specific cases in the context of Brazilian peculiarities, and they do so in the light of theoretical and doctrinal models and conceptions with reference to historical and social reality that those jurists conceive as being universal, according to Western and European criteria they adopt in their works. This means that they produce the same abstractions and dichotomies that legitimized the emergence and the development of Western modernity and its universal ideas and thoughts.

As for Sarmento's thought, emphasis will be given mainly to the 
analysis made by him of constitutional norms on minority rights, as well as his conception of constitutionalism and the Brazilian Constitution of 1988. Regarding Barroso's ideas, the analysis of his interest and concern for fundamental rights will be preceded by the presentation he makes about the historical and philosophical antecedents of contemporary Brazilian constitutionalism. The comparison and confrontation between the two constitutionalists are intended not only to establish the similarities and differences in explaining the relationship between constitutionalism and constitution and point out the innovations in constitutional matters, but mainly to know whether and to what extent it is possible to speak of paradigmatic change as legitimate recognition of the historical and social reality of Latin American constitutionalism through Brazilian constitutionalism.

The rationale underlying this theoretical and methodological approach is grounded on the distinction by Hokheimer between "traditional theory", which is descriptive of reality and is referred to the separation between the individual and the society, and "critical theory", which is based on the critical behavior and on the understanding of the fragmented reality as a contradiction of the social system itself. If the former does not produce emancipation, the latter generates transformation. After all, critical theory "dispenses the pragmatic character that comes from traditional thought as a professional matter that is socially useful" (HOKHEIMER, 1980: 131).

The production of conditions for thought in accordance with the logic that ensures the confrontation with the traditional categories of Western thought is the epistemological condition for the recognition of the "novelty" in the Brazilian constitutionalism based on the innovations enshrined in the Brazilian constitution in the context of political and social change in Brazil and also in Latin America. This relates to the "machine for intellectual decolonization and therefore for political and economic decolonization" (MIGNOLO 2003: 76). This border thinking lets face "emancipatory rhetoric of modernity from the cosmologies and epistemologies of the subaltern, located in the oppressed and exploited side of the colonial difference" (GROSFOGUEL, 2008: 138). The border issue also allows thinking in theoretical terms the issues of this study as to the historical relationship between past and present, between yesterday and today, often despised by Brazilian constitutionalists. Recognize that the present is "the current time" (Benjamin, 1989: 191) means that the past is always open, and so it is not closed on the facts already produced. The past will not have accomplished everything, and there remain things to be done in the present. It is this past that is destabilizing of current modernity in Brazil and Latin America, and it should operate as a condition for the production of authentic thinking in the field of constitutional law. 
These theoretical frameworks will allow not only to face the problem constructed in this work but also to point in the direction in which it is possible for constitutionalists to approach constitutional peculiarities of the Brazilian Constitution of 1988 and also to consider the changes in the Brazilian constitutionalism referred to the ways of thinking and explaining the processes of formation of the State and the Society themselves.

\section{Brazilian Current Constitutionalism and The Minority RightS}

Daniel Sarmento conceives the emergence of the Brazilian constitution of 1988 as the crowning achievement of the transition process from authoritarian regime to democratic regime. While recognizing in the Constituent Assembly the presence of powers that gave support to the "authoritarian regime", he acknowledges that this fact did not prevent the drafting of a constitution with "deep commitment to the fundamental rights and democracy" (SOUZA NETO, SARMENTO, 2012: 170). He also points out the influences that the Portuguese constitution of 1976, which exceeded the authoritarian regime in a revolutionary way, and those of the Spanish constitution of 1978, which achieved the same result by an agreed transition, exerted on the Brazilian constitution.

When this constitution was enacted in 1988, it had 245 permanent articles and 70 temporary constitutional provisions. It emerged therefore as a long and analytical charter. The author of Livres e Iguais still defines the constitution as "a compromise charter", because it does not represent the "crystallization" of a pure and orthodox political ideology. He claims that it was the result of a compromise between various interests and political forces in the Constituent Assembly. He further qualifies the Brazilian Magna Charter as being director and programmatic of its nature. If it "is not limited to organize the state and list the negative rights" (SOUZA NETO, SARMENTO, 2012: 171), it continues "providing positive rights and establishing goals, objectives, programs and tasks to be pursued by the state and the society", Sarmento asserts.

The elaboration of the Brazilian constitution of 1988 arouses attention when it is compared with previous constitutions. The preWorld War II Constitutionalist movement was concerned with the structure of the state. In the post-World War II, it went on to enshrine fundamental rights and guarantees. These rights were generally listed in the first chapters of the constitutions and only in later chapters there was concern about "disciplining state organization." The Brazilian Constitution of 1988 adopted the same innovation.

It has its high point on fundamental rights. On grouping civil 
and political rights, the Brazilian Charter guaranteed social rights and added to itself, in Sarmento's words, rights of third dimension. In this sense, it showed concern about the enforcing of these rights, a fact that can be confirmed through the provision of article $5, \S 1^{1}$. Also according to Sarmento, the Constitution regulates the same time as it turns its attention to the most vulnerable subjects of Brazilian society. It proceeds "to the defense of women, consumers, children and adolescents, the elderly, indigenous peoples, Afro-descendants, quilombola [descendants of slaves], disabled people and prison inmates" (SOUZA NETO, SARMENTO, 2012: 173). Citing permanent articles such as articles 215,216,231 and the temporary article 68, the constitutionalist argues that the Brazilian constitution consecrated "some openness to multiculturalism, to take charge of the protection of different cultural and ethnic identities that comprise the Brazilian nation." Despite this, he acknowledges that conservative constituents considered the fundamental rights of the Constitution more as "props to embellish" than as rights endowed with practical significance.

As far as the organization of the three powers is concerned, the Constitution expanded the powers of the Legislature and the Judiciary designated as required for a political system that aims to overcome the authoritarian period. The Executive power was strengthened with the prerogative to issue interim measures and to maintain the control of the 'parliamentary agenda.' However, according to the dominant political engineering, the executive always depends on the legislative majority and on the necessary alliances to build parliamentary majority, a fact that some constitutionalists call "coalition presidentialism".

The Legislature, in comparison with limiting military regime, was reinforced as for the production of standards and the oversight function of the other powers. However, the change that has generated more debate is that concerning judiciary.

By arrangements made with numerous instruments of judicial review, combining an extensive and invasive Constitution, it has become difficult for some more relevant political decision not to be subjected to the judiciary, which often decides against the wishes of the other branches of government. This phenomenon, which has become more acute in recent years, has raised complex questions about the limits of democratic legitimacy of the actions of the judiciary, since its members are nor elected neither dismissible by popular vote, and that often the Judiciary decides highly controversial issues based on the exegesis of constitutional clauses and open spaces, which are subject to different interpretations (SOUZA NETO, SARMENTO 2012: 175).

Thus, the debate is open with respect to the possibility about the

1 The provisions defining fundamental rights and guarantees are immediately applicable. 
weightings between constitutional principles and values ${ }^{2}$.

A phenomenon that can be seen as a result of a constitution that is as extensive as analytical as it is the Brazilian constitution of 1988 is called "constitutionalization of the law" by Sarmento.

It is almost impossible today to find a lawsuit in any area - civil, criminal, labor, etc. - in which the Constitution is not at some moment invoked by the litigating parties and then employed by the judge or the court to reason their decisions. But it is not only in the courts that this phenomenon takes place. Constitutional discourse has, to some extent, penetrated into the parliamentary debates, the claims of civil society and even in the routine of technocrats, (SARMENTO, 2009:167).

In short, the conclusion at which Sarmento arrived is that the 1988 Constitution, unlike the constitutions of other times, has been present in various ways in day-to-day lives, in the main events of the Brazilians, and especially in the demands of social movements.

From a theoretical point of view, the affiliation underlying the author's works can be deduced both from the substantialist and the proceduralist currents. The former imposes limits on political deliberations; the latter refuses limits to the democratic system of deliberation.

One of the leading exponents of procedural theory, and affiliated to the Frankfurt School, Jürgen Habermas has criticized the role of the German Constitutional Court regarding its view of the constitution as an "order of values", thus pointing out the "undemocratic and paternalistic nature" of this conception (SOUZA NETO, SARMENTO, 2012: 225):

By letting itself be led by the idea of conducting material values, preliminarily taken for granted in constitutional law, the Constitutional Court becomes an authoritative instance. In the event of a collision of rules, all the reasons may assume the character of arguments geared towards the realization of objectives, a fact that makes collapsing the corner stone introduced in legal discourse by deontological understanding of standards and principles of law (...). As a constitutional court adopts the theory of the order of values and takes it as the basis of its decision, grows the danger of irrational judgments, because in this case the functionalist arguments take precedence over the normative ones (HABERMAS, 2003:321 - 322).

Inversely, substantialism endorses the legitimacy of substantive decisions regarding fundamental rights. In this sense, A Theory of Justice, by John Rawls, first published in 1971, may be cited as a paradigm that influenced this doctrine:

Each person should have an equal right to the most comprehensive overall system of equal basic liberties compatible with a similar system of liberty for all; social and economic inequalities should be arranged

2 Hence the debate about the legitimacy of the judiciary to decide important issues. 
so that, at the same time, they: (a) bring the greatest benefit to the least advantaged, obeying the constraints of just savings principle, and (b) are linked to jobs and open positions to all under conditions of fair equality of opportunity (Rawls 1976: 3-4).

Combining the two theories in a brief summary, two conclusions can be inferred from the thoughts of the Brazilian constitutionalist. First, it is legitimate to set limits for the majority of every moment, especially when they are linked to the protection of fundamental rights and to the access to the democratic process itself. Thus, he believes that the Constitution gives the judiciary the power to enforce these limits (SARMENTO 2009: 186). Second, the Constitution cannot be considered as a source capable to provide answers to all national problems. "A minimally committed constitutional theory to democracy must recognize that the Constitution leaves several spaces of freedom for the legislature and for individuals, in which the political autonomy of the people and the private autonomy of the human person can be exercised" (SARMENTO 2009: 186).

Thus, the author of Constitutional Law is in favor of a constitutional model that should be enough opening for political deliberations "of each generation," and he is against the excesses of the substantialism in constitutional theory in order not to limit its democratic components. However, he recognizes substantialism as a possibility when the protection of the human being concerns the fundamental rights of minorities against majorities in the democratic process. In this case, Sarmento states that the judiciary plays an important role.

In this context, interpretation given by the Brazilian constitutionalist to the constitutional provision that expressly refers to the right to possession of the territory occupied by descendants of slaves makes this provision clearer. He recognizes substantialism as a possibility as for the protection of minorities. For Sarmento, the article 68 establishes a fundamental right $^{3}$. Based on a teleological reading combining $\S 1$ and $\S 2$ of the article 5 of the Constitution, the right to land of the quilombolas can thus be linked to the fundamental right to culture, according to the article 215 of the Constitution, and this right binds to the cultural identity of the community members.

Thus the article 68 would provide the territories of the quilombola communities affected to the government with specific public purpose, and it would not relate to a simple property right, but to a guarantee of the existence of the quilombolas as a right holder. Thus, the quilombolas could avail themselves of all legal instruments for the defense of such a right to the detriment of third parties or the owner himself. Thus, the article 68 would be directly

3 To the remaining communities of descendants of slaves who are occupying their lands is recognized the property outright, and the State shall send them deed of proporty. 
linked to the principle of human dignity - an axiological standard that underlies the whole constitution. This principle should thus be invoked to preserve the identity and culture of the Quilombolas.

Moreover, Sarmento uses the philosophy of recognition to support the right of minorities in the Brazilian constitution, especially the one by the Canadian philosopher Charles Taylor.

From this most appropriate anthropological perspective, it was possible to build, for example, the idea of the "right to recognition", claiming respect for collective identities of non-hegemonic groups, given the fact that the social devaluation of groups tends to hurt deeply the dignity of each of its members. When, for example, society fails to appreciate black culture and the importance of his legacy to the country; when it values only the European contributions to the formation of the Nation, prioritizing their values and their aesthetics, it hurts directly the self-esteem of black people, who may even compromise their ability to independently formulate and follow their life plans, as enforced by the liberals. The understanding of this form of exclusion, which is not necessarily related to economic oppression, and the search for remedies to combat it are on the basis of the so called "politics of recognition", which have unequivocally emancipatory dimension. The Brazilian constitution of 1988 has clear openings for this emancipatory bias characterizing communitarianism (...). This is clear, for example, in article $216, \S 1$, of the Constitution, which imposes to the State the duty to protect "the expressions of popular, indigenous and Afro-Brazilian cultures, and other groups participating in the national civilizing process" (SOUZA NETO, SARMENTO 2012: 213 ).

Last but not least, Sarmento claims that the Brazilian constitution demonstrates thus openness to communitarianism. However, he points out that one should not confuse it with a "community" Constitution. The Charter of 1988 is a social constitution "that is concerned with the protection and promotion of national culture (articles 215 and 216 of the Constitution) and consecrates trans individual rights, collective ownership" (SOUZA NETO, SARMENTO 2012: 214).

\section{Historical and Philosophical Background of the current BRAZILIAN CONSTITUTIONALISM AND THE FUNDAMENTAL RIGHTS}

Barroso understands jus naturalism as a philosophical current that defines law based on the existence of natural right. Thus he acknowledges that there are in society "a set of values and legitimate human pretensions that do not arise from a legal rule emanating from the state, that is, independent of positive law (BARROSO, 2004: 318).

According to him, the explanation of that right would find its roots in Hugo Grocio's philosophy. In the first half of the seventeenth 
century in Europe, he developed the idea that natural law is the set of rights that should be recognized as valid by all people, regardless of divine will and that it was endowed with its very existence. $\mathrm{He}$ recognizes in Grocio's thought the start of the Thomistic reasoning to the humanities. The influence of St. Thomas Aquinas is recognized by Barroso as "the most influential" with respect to the philosophical system he developed during low European middle ages, delimiting boundaries of acting and reasoning between faith and reason: "Preaching that law is an act of reason and not of will, he distinguished four kinds of law: eternal law, natural law, human positive law and divine positive law "(Barroso, 2004: 318). The influences of rationalism are felt in practice as regards the recognition of written documentation, of compiles rules, as the source of law, applicable, due and enforceable. And this is to protect law from religious and metaphysical interpretations until then in force and externalized by the sovereign will of absolutist rulers.

For the Brazilian constitutionalist, jus naturalism therefore puts forward, as an important influence for both contemporary and modern law, the ruptures produced in relation to the medieval scholastic thought. As influences for modern constitutional law, jus naturalism states the recognition of man as a being whose existence and destiny are no longer subject to the metaphysical principles, values and norms of religion. By joining the Enlightenment in the eighteenth century, jus naturalism asserts the need for the state to be recognized as an abstract entity possessing abstract principles and objectives and being detached from the person of the ruler.

The Constitution is the document that regulates par excellence these principles and objectives of the State and delimits by describing and limiting the relations between state, government and society. As a written text, it has the power to clarify and link the actions of the State, the Government and its citizens, by prescribing to them accurate legal consequences. The School of exegesis, by prioritizing allegiance to the legal text as a way of maintaining and developing socioeconomic existing order, releases constitution of any whims and arbitrariness, especially on the part of government.

For the contemporary constitutional law, jus naturalism is presented as the systematizer of the constitution as an institution that underlines obedience and linkage between State, Government and Society. This fact made possible the development of the liberal state, based on an economy and a social context in which the autonomy of will could only suffer the limitations prescribed the Constitution, a fact that objectively subordinated the action of state and government to the constitutional provisions laid down by a Constituent Assembly composed of the representatives of the people, who were also the representatives of the industrial and bourgeois majority. 
According to Montesquieu, the tripartite division of powers - in its classical form, with emphasis on the complete independence capable of producing perfect harmony between legislative, executive and judiciary - aimed to assign the judiciary the power to judge not only according to the law, but mainly and strictly as to the letter of the law, without any other further possibility of interpretation than that of grammatical, historical and teleological.

As for Barroso, this theoretical and methodological alliance between the jus naturalism and the School of Exegesis also represented the historical overcoming of jus naturalism, because the literalness in the interpretation and application of legal rules did not allow any possibility for external values to penetrate into the law: natural law was then considered to be metaphysical and unscientific. It was sidelined on behalf of the prevailing positivist movement in the nineteenth century, and positivism became, "in the first decades of the twentieth century, the philosophy of the jurists."

Instrumentalized by the school of Exegesis, legal positivism was presented as an effective weapon for maintaining the socio-economic order established by the French Revolution. It had as its theoretical basis Comte's classical positivism, as its philosophical foundation St. Thomas' thought, and as its methodological basis the Enlightenment. "The man had come to his rational age, and all had become science: the only valid knowledge, the only moral, even the only religion. The universe, as disclosed by Galileo, would have a mathematical language, integrating a system of laws to be discovered, and the valid methods in the natural sciences should be extended to the social sciences "(Barroso, 2004: 322).

The author of Interpretation and Application of the Constitution asserts that the heyday of legal positivism occurred with Kelsen's positivism, whose main characteristics are: a) the complete approximation between law and norm; b) the emanation of law from the state; c) the completion of the legal system; d) the validity of the norms dependind of the procedure adopted in their creation, regardless of their contents.

The Brazilian constitutionalist states that for the jurists of the twentieth century, the extreme reduction to which the right was taken, as a set of independent rules within a closed system, was unable to guarantee the neutrality of interpreters in law enforcement. Quite the contrary: he notes that law has never failed to be a means of maintaining of social order. And to achieve this result, the methodological mechanism of legal positivism proved to be quite effective in that it allows no influence from any other value, knowledge or moral criteria in the application of pre-established rules.

Barroso points out two major political and military movements 
as the historical landmarks of the decay of legal positivism: Italian fascism and German Nazism.

At the end of the Second World War, the idea of "a legal system indifferent to ethical values" and that of the law as a purely formal structure (a packaging for any product) were not more accepted in the enlightened thinking. The historical supersession of jus naturalism and the political failure of positivism gave way to a wide range of reflections on the law and its function and social interpretation. Post-positivism is just a provisional and generic designation of a diffuse set of ideas, under which are included the definition of the relationships between values, principles and rules (the so called new hermeneutic aspects) and the theory of fundamental rights (BARROSO, 2004: 325).

Barroso features neo-positivism as the "return to values, a rapprochement between ethics and law" (Barroso, 2004: 326), a fact that does not mean the reincorporation of abstract and subjective metaphysics in law. This means the redemption of natural law values that should be included in the closed system of interpretation and application of positive law, this time with ethical and objective criteria founded on the dignity of the human being. The Kantian turn is sustained by Barrroso as a socio-philosophical movement enriching man and his nature as a radiating center of validity, both of the contents of legal rules and of the interpretation and application of legal rules in particular cases. Freedom, equality and material life of man became the vectors of validity, enforcement and interpretation of legal norms, elevated to the category of fundamental rights, through the redefinition of the legal and social function of "legal principles". Such vectors were then characterized as legal principles, endowed with the same effectiveness of legal norms in the event of the existing legal rules governing such matters in a certain legal system are not sufficient to respect the dignity of the human being in particular cases.

The novelty of the last decades is not exactly the existence of principles and their possible recognition by the law. Principles coming from religious, philosophical or jus naturalistic texts have a long time pervaded reality and imagination of law, directly or indirectly. (...) The constitutional principles, therefore, explicit or not, become the synthesis of the values laid down in the legal system. They mirror the ideology of society, its basic assumptions, and its purposes. The principles provide unity and harmony to the system, and they integrate its different parts and attenuate normative tensions. (...) On the trajectory leading to the center of the system, the principles had to gain the status of a rule, overcoming the belief that they had a purely axiological and ethical dimension, without legal efficacy or direct and immediate applicability. The modern dogmatic endorses the view that the standards in general and the constitutional norms in particular fall into two major different 
categories: the principles and the rules. Generally, the rules contain more objective reporting, with their application restricted to specific situations to which they are addressed. As for the principles, they have higher levels of abstraction and a more prominent purpose in the system. There is no hierarchy between the two categories, in view of the principle of unity of the Constitution. This does prevent the principles and rules from performing different functions within the system (BARROSO, 2004: 328).

And even more:

The qualitative distinction between rule and principle is one of the cornerstones of the modern constitutional dogmatic, fundamental to the overcome the legalistic positivism, according to which rules remained, connected to legal rules. The Constitution starts to be regarded as an open system of principles and rules, permeable to supra positive legal values, in whose scope the ideas of justice and the realization of fundamental rights play a central role. The paradigm shift on this matter is particularly tributary to systematization Dworkin's systematization. His elaboration on the different roles played by rules and principles earned universal acceptance and became the consensus regarding the subject (BARROSO, 2004: 328).

Barroso is influenced both by the conceptual distinction between principles and rules and the functional distinction made by those authors, for the purpose of enforcement of fundamental rights, especially in the field of collision of fundamental rights. He makes this distinction in order to affirm the need for the human rights to be effected once classified as normatively principles and despite the concrete situation to which those rights are referred. This reasoning seeks to prevent, in a concrete situation, a fundamental right from being rejected by the full and complete implementation of another right, if it were only considered as a rule in strict accordance with classical positivism. The aim of characterizing the fundamental right as a principle and as a legal norm (post-positivism), and not as a rule, is to minimize the contempt for fundamental right that would be disregarded.

Rules are legal provisions provided with specific and determined contents and specific addressees. They are to be applied to court cases in the hypothesis whether or not the real fact is submitted to the norm. Due to their high valuative load, the principles have legal high density and therefore they will be turned to specific addressees whose 
concrete cases will only be individualized when they will happen in the real world. The principles are generic, provided with indefinite legal contents and high density because they may be related to various specific cases, even in the hypothesis of apparent collision between two or more principles applicable to a particular case. Therefore, principles will be only applied to particular cases after their contents are set in respect to social and legal requirements regarding the case.

Rules are normative propositions applicable according to the rule of all or nothing. If the facts laid down by the rule come to occur, the rule must be directly and automatically applied, producing thus its effects. (...) Generally, principles grounded in greater valuative load, ethical foundation, relevant political decision, and they point out a particular direction to follow. It happens that, in a pluralistic order, there are other principles that comprise decisions, values or several fundamentals, sometimes contradictory. The collision of principles, therefore, is not only possible but it is also part of the logic of the system, which is dialectical. So their application cannot be carried out in terms of "all or nothing", of validity or invalidity. It should be recognized to the principles their importance and value. In view of the facts of the case, the interpreter should make choices in a reasoned manner when he confronts inevitable antagonisms, such as those that exist between freedom of expression and right to privacy, free enterprise and state intervention, the right to property and its social function. The application of principles takes places predominantly through a process of weighting (BARROSO, 2004: 329).

Habermas understands that principles and values are vectors that unify demands for access to the democratic process, so that requesters should use democratic procedural instruments provided for in the Constitution in order to demand legislative reform to meet their demands. Dworkin (1977) and Alexy (2011) understand that principles are norms capable of solving concrete cases whose applicable legal rules do not offer a legal solution based on the enhancement of human dignity, a fact required by litigants. Such demands must be met regardless of prior and specific legislative amendment. Under Brazilian law, legal rules and principles laid down in the 1988 Constitution form a set of "rules of low valuative strength, applicable in the everyday life." The author of Interpretation and Application of the Constitution is critical to this situation because he considers that it is important to value principles as legal norms laid down in the 1988 Constitution. According to Barroso, the interpretation of norms already written and laid down may by law do lead or not to the application of rules "in a fair way", thus valuing and effecting fundamental rights. It is the "new constitutional interpretation" whose goal is the preservation of traditional concepts allied to ideas that 
announce new times and meet new demands (BARROSO, 2004: 346).

These new demands would be those that result from postmodernism, which is portrayed by Barroso as the individualization of the individual as a subject of law - and not the object of law - who must accomplish his or her intellectual, social and cultural potentialities. The rules that were already laid down and addressed to specific and individual cases in the context of a sociocultural positivist era, and before globalization time, do not solve these "new demands" because those rules are referred to distinct theoretical and methodological foundation. Therefore, given the inability of the Executive and the Legislature to meet the needs represented by those "new demands" through rules and enforcement of rules, the individuals - the new plaintiffs- are forced to resort to the courts in order to have their rights applied. The judiciary, particularly through the exercise of judicial review, would thus be legitimated to meet such demands, and the instrument that would be available to them would be just the use of the principles of the fundamental rights as vectors of weighted principles as vectors as normative standards or state power to justify not application prejudicial to the dignity of the human person in this case rules.

This is the political use of the legal system in order to accomplish rights until then not entitled. The main agent would not be only the judiciary, because it just receives the demands and has the constitutional duty to provide judicial protection based on the specific case according to the constitutional principle of the unrestricted access to justice. And as it would not be able solve the case brought before it by applying only rules according to the classical positivist method; it is obliged to apply principles that serve as the foundation for the "new demands". The main agent is then the interpreter in so far as this category includes all persons who deal with specific cases in justice, ranging from the members of the judiciary to other legal professionals by going through individuals, social groups and social movements that identify and individualize the "new demands" to the State.

Barroso recognizes the importance of the role of the interpreters in the Brazilin constitutional order since 1988, especially those who operate in the judiciary for the purpose of producing positive and fair results in the requests that do not meet legal support in the established rules. This is because the role of the interpreter is to deduce from principles the norm able to bring the solution for the case brought to trial.

Facts and interpreters have always been present in constitutional interpretation. (...) In several situations, especially those regarding the collision of legal rules and constitutional rights, it is not possible in theory to deduce from the system the appropriate solution. It can only be formulated in view of the facts referred to the case (...), and it allows to state what outcome corresponds to the constitutional will. 
Furthermore (...) it is necessary to know if the application of the norm to the case carries out the constitutional law. (...) The modern constitutional interpretation involves choices by the interpreter as well as subjective principles of integration, open standards and indeterminate concepts. Much of the scientific production has been focused precisely on the study of the restriction of judicial discretion trough the definition of criteria weighting values and interests (...) (BARROSO, 2004: 360 -361).

The political function of the interpreter is described by Barroso as based on the Argumentation Theory, which assigns the interpreter the function to investigate and defend from possible interpretations the one which is the more accurate, i.e., the one that can present a consistent and rational foundation for the studied case (BARROSO, 2004: 363).

The constitutionalist presents the following constitutional principles that he regards as fundamental to the interpretation: legal superiority of constitutional norms (BARROSO, 2004: 369), open and indeterminate nature of the constitutional language and specific contents and political character of constitutional norms (BARROSO, 2004: 369).

\section{The Constitutionalism BY The Constitutionalists IN QUESTION}

The predominantly doctrinal and rhetorical approach to the relationship between constitution and constitutionalism in legal works by Sarmento and Barroso expresses mainly their practical interest in the interpretation and application of the Brazilian constitution regarding conflictresolution by the Judiciary. In this sense, the two constitutionalists wander from constitutionalism as a doctrine that focuses on problems of different nature. For example, they do not question about the particularity of the Brazilian or the Latin American constitutionalism. They do not take into account the fact that the development of these expressions of constitutionalism follows the same standards and principles originating in the Western cultural reason, a fact that implies the denial of their history. "To deny our origins is a curse that crosses our Latin America [and also Brazil]. It is a damn that is based on the criterion of (...) modernizations without modernity "(ROSENMANN, 2008: 09). Both constitutionalists recognize the importance and expansion of the role of the Judiciary in enforcing rights related to the changes advocated by the Brazilian Constitution of 1988. Barroso addresses the issue of new demands, individual or social demands, in the context of what he called "postmodernity". Sarmento shows concern about the supervision of the limits to be set on the relationship between majorities and minorities.

Sarmento seeks to explain the production of the Constitution on the basis of a normative axis and a political plan. After all, the Brazilian constitution resulted from the influence of both Portuguese 
and Spanish constitutions as well as the from political forces and divergent national interests that constituted the Constituent Assembly. Barroso approaches the Brazilian constitution in such a neutral manner as if it was "a written paper" that makes the "crossing" between legal facts - the established order - and political facts - the Constituent. Sarmento characterizes the constitution as a "possible compromise" between antagonistic forces and interests in the Constituent Assembly. The political nature of the Constitution can be recognized as the fact that it expresses the "crowning" of the transition from an authoritarian regime to a democratic system. For Barroso, the political dimension of the Constitution is related to the function that performs its interpreter as the investigator and defender of the interpretative possibility the most accurate.

However, none of the two constitutionalists take into consideration the empirical and critical knowledge about legal and constitutional reality in the light of modernity or postmodernity crisis. Each of them proceed as if they produced the interpretation or the interpretative model to which the facts to be analyzed would be mechanically submitted. "Set their location [the location of the facts in time], their ability to change, the determinations that make it possible to explain their specificity, it does not enter the field of conditions over which should begin the discussion to explain their operation" (ROSENMANN, 2008:18).

The relationship between the Constitution and the society is not addressed in the same way by both constitutionalists. For the author of Interpretation and Application of the Law, the second term of this relation is represented by the "new social demands", and it depends on the exercise of judicial review by the judiciary through "the principles of fundamental rights." For the author of Free and Equal, that term transcends the limits of legal proceedings to accommodate social justice claims, political debates, and technical decisions, even from the standpoint of speech. Sarmento calls this situation "constitutionalization of the law." Even though the theme of "universality" does not disappear from the works of both constitutionalists, it seems mainly to justify concern about certain kind of philosophical attitude "more concerned with the effective action than with theory. A philosophy that shows the possibilities of this action and its possibleeffectiveness"(ZEA, 2005:484).

From the standpoint of theory, the rationale of constitutionalism in the light of interpretative models of the Brazilian Constitution delimits the field where it is possible to recognize the differences between Sarmento and Barroso. On concrete and different situations, Sarmento lets know the influences he undergone from both Habermasian proceduralist conception and Rawlsian substantialist formulation with regard to the issue concerning the acceptance or rejection of limits on the democratic political deliberations. Dworkin and Alexy are the main 
influences undergone by Barroso. However, neither of the two Brazilian constitutionalists seeks to study the gray and silent areas that allow distinguishing Brazilian constitutionalism from European and American constitutionalisms and approaching Brazilian constitutionalism to Latin American constitutionalism. They not even dared to think the fact that Latin America was the birthplace of "the historical process that defined the historical and structural dependence of Latin America and that it was that process that, at the same time, led to the constitution of Western Europe as the world center of control of that same process.' (QUIJANO 2006: 49).

By accepting substantialist formulation in order to defend the rights of minorities, Sarmento adopts the conflitualist conception of society and recognizes the role of guardian of the judiciary under whose context he considers minorities and majorities in situation of opposition. However, he does not take into account neither the concern about the overcoming of utilitarianism and perfectionism nor Rawlsian liberal thesis about the good life for citizens and the defense of this life by these same citizens. Moreover, the Habermasian proceduralism implies the conception of social consensus and the rejection of limits imposed by the values, mainly by the material values. As Habermas, Sarmento thinks over the values in the light of the functionalist perspective and he opposes such values to normative arguments. He does not consider Dworkin's substantialism regarding the access to democracy on the basis of historical continuity. Had he done so, he possibly would have come to the followings results. On one hand, to consider the constitutional principles as the substantive contents of the constitutional order and in a position to resolve "empirical problems" referred to social inequalities based on the pragmatic function of law. On the other hand, by distinguishing between Rawls' and Dworkin's substantialism, to substantiate Habermasian proceduralism, which presupposes the historical rupture that can logically explain the adoption of constitutional principles as a result of an "ethical agreement" valid to societies and states emerging from authoritarian and totalitarian forms of government. However, neither Sarmento nor Barroso problematize functionalism as do the social sciences. The idea that society works well, for example, is not questioned. Moreover, they exclude normative arguments and categories from the functionalist field and analysis. The idea that the rules run above and outside the range of values, for example, is taken for granted, that is, it is accepted as a fundamental principle.

As to the question regarding Habermasian proceduralism, Barroso describes the post-positivist and jus-philosophical movement as a theoretical and philosophical result of the Critical Theory of Law. However, he extends - or reframes - the validity of the Critical Theory of Law so as to take into consideration the theoretical contributions 
by Dworkin and Alexy. Or otherwise, it does not come to talk neither about expansion nor about redefinition, but about the mere importation of theoretical formulations in a mechanical and passive manner. Barroso is not clear as to the objective of deepening the theoretical and methodological ruptures between Dworkin and Alexy and the Frankfurt School. His main purpose seems to be to describe, to justify and to argue favorably on the characterization of principles as legal norms, as being as effective as the rules. Moreover, the author of Constitutional Law does not problematize nor Dworkin's liberal nature and individualistic conception of society neither Alexy's theory of fundamental rights in his reference to the German constitution.

Barroso is not concerned with the explanation about the refusal of Habermasian proceduralism as a method of effectiveness of law. He shows no interest in explaining the reasons for the rejection of Habermasian jus-philosophical contribution to neo-positivism and the neo-constitutionalist movement of the twentieth century.

This negative dimension of his thought may be explained by two reasons. First: the concern of the constitutionalist to promote a historical and functional introduction of the law, since the conception of the modern state Constitution, from the American and French Revolutions to the post-World War 2nd as facts that triggered the need for changes to the legal and normative features characterizing principles so as to ensure the adaptation to the legal and social system in Brazil of the XXI century. This is the reason why he characterizes the Critical Theory as a theoretical foundation of neo-constitutionalist movement. Second: through specific conception of postmodernity, Barroso portrays humanization and individualization of social needs as socio-philosophical foundations that promote the extension and deepening of the normative effectiveness of constitutional principles.

However, when it comes to recognize "the others" and "their differences" on the question of minority rights, Sarmento seems to abandon Rawls' substantialism to claim Taylor's communitarianism. This is such a theoretical shift that allows Sarmento to affirm the emancipatory character of communitarianism to the Brazilian Constitution and recognize the role of legal and social policies for recognition of democratic governments. Moreover, this "communitarian turn" does not hide the distinction between communitarian constitution and social constitution made by Sarmento. As a social constitution, the Brazilian Constitution of 1988 aims at the promotion of national culture, besides consecrating trans-individual rights and collective holders of rights.

The question of the universal and particular dimensions of law is differently approached by Barroso. His historical and functional introduction of law depends on three aspects: the socio, economic and political functionalities of law, the state and legal power structures 
and the theoretical and philosophical conceptions underpinning the first two aspects. As for the functionalities of the law and the powers of state, they are broadly and deeply presented as defining the model of the Liberal State. As for the functional changes that the powers of State and the law have undergone during the Social Welfare State, they are timidly defined. Then again, he presents quite deeply the socioeconomic consequences of the superposition of these models, associated with the effects of economic and social globalization, so as to justify his particular conception of postmodernity as a historical moment of valorization of the individual potentials. And in so doing, he assigns a universalizing character to the human beings as for their need for protection by the State and an individualizing character as for their peculiarities, which should also be subject to protection.

Barroso and Sarmento understand that the legal principles should have their contents and socio-legal functions reinterpreted from the classic positivism to the post-positivism. This is the condition for the realization of human dignity as a vector of the legal system. However, they differ on the instrumentalization and the enforcement of this reasoning.

Whereas for Barroso, the constitutional principles "reflect the ideology of society", for Sarmento the Constituent Assembly is characterized by the absence of "pure and orthodox political ideology", as well as the Constitution and the constitutional rules and principles. Whereas Sarmento's argument allows asserting "the compromising character" of the Brazilian Constitution of 1988, Barroso's argument assures to support the effectiveness of constitutional principles, in so far as they are normatively ranked as fundamental rights, regardless their concrete situations.

In this sense, Sarmento's argument is consistent with the view that the Brazilian Constitution reveals the same emancipatory character featuring the community perspective. Unlike Sarmento, Barroso's reasoning shows concern about the neutrality of interpreters in the context of constitutional law as "a set of independent rules inside a closed system". To affirm "the return of values" provides for Barroso the opportunity to define neo-positivism through the relationship between ethics and law and to recognize a "new constitutional interpretation". To deny the "order of values" provides for Sarmento the opportunity, in the footsteps of Habermas, to recognize proceduralism as a method for the interpretation of Brazilian Charter. The reasoning of both constitutionalists leads to the same result: the naturalization of the constitutional categories "fundamental rights" and "human dignity". Neither the use of Taylor's communitarianism by Sarmento nor Barroso's concern with the historical background of the Brazilian constitutionalism produces reflection of sociological and historical nature. Perhaps the influence of Bobbio's systematizing and moderate thought and the 
influence of Taylor's decontextualized communitarianism stand for the difficulties of the Brazilian constitutionalists as to the recognition of the need to distinguish the value and the meaning of constitutional categories such as "fundamental rights", "rights of minorities" and "human dignity" from a legal, historical and social point of view.

Anyway, the studies of the Brazilian constitutionalists show the limits in respect for which it is necessary to "be vigilant and suspicious to the extreme, to avoid - by critics and consultation to reality - the resumption of alienating models of reflection" (BONDY, 1982:132) caused by the use of imported values and concepts.

\section{Conclusion}

Barroso's concern with the historical and philosophical background of the current Brazilian constitutionalism as well as his use of some categories of thought by Dworkin and Alexy do not lead the Brazilian constitutionalist to produce historical works or a philosophical reflection. Sarmento's concern with the community character of the Brazilian Constitution as well as his use of some philosophical and political categories of thought by Taylor are not enough to place minority rights in Brazil in a specific social and historical configuration. This may account for the more topic and rhetorical character of the dogmatic formulations of the two Brazilian constitutionalists who show greater practical and professional preoccupation with conflict resolution within the framework of constitutional law and through it.

Sarmento's concern with the reasoning focused on the defense and enforcement of the rights of real minorities leads the constitutionalist to proceed in a traditional manner. Theoretically and methodologically, he adopts the perspective of the classic dichotomies and places proceduralism and substantialism in the field of mutual and reciprocal exclusions. The ontological ruptures he uses are less liable to criticism because they are used in view of his preoccupation with the concrete reality of minority rights. In this case, he seems to establish some principles for interpretation and application of the Constitution in Brazilian society according to the association that he ends up doing between proceduralism and generality, on the one hand, and substantialism and particularity, on the other hand. Nevertheless, contemporary constitutionalism should claim an approach that should be able to cope with the question concerning integration between generality and specificity, and not a perspective that should underpin such a cleavage.

Barroso's concern with the interpretation and application of the Brazilian Constitution in society takes the constitutionalist to lean less on the rights of minorities than on the question of human 
dignity. By proceeding in a rhetoric and dogmatic way, he makes use of the argumentation theory and the distinction between rules and principles for defining human rights as fundamental principles of the Brazilian Constitution endowed with normative function and so as a criterion for the interpretation and application of the constitutional law.

Thus, according to the Brazilian constitutionalists, the current stage of the Brazilian constitutionalism is primarily the result of the political and social processes that resulted from the correlation of distinct and contradictory forces and interests in Brazilian society and also from the participation of various and social movements and sectors of civil society, and all this gave rise to the National Constituent Assembly meeting. Despite this, both the Constituent as a "product" and the political and social interests and forces as a "process" appear primarily as a figure of rhetoric in the ideological universe of the two constitutionalists. Paradoxically, the changes in the so-called "constitutional law" define both the political ruptures with military authoritarianism, by the advancement of the process of democratization of Brazilian society, and the theoretical, dogmatic and methodological continuities, that define the limitations of the Brazilian constitutionalists to the problem of incorporating into their reflections the constitutional reality and the Latin American constitutional thought.

The consequences arising from this framework do not prevent the realization of analysis of conjuncture on specific situations concerning the Brazilian reality and relating to the "holder of right" and the "right of holder" in the field of minority and fundamental rights.

Those consequences notwithstanding, the fact is that they define the limits of Brazilian constitutionalism in terms of reflection in the context of the critical theory of law facing the problem of emancipation and transformation. Even if such limits can be credited not to the analysis of the works of the authors as a whole, but to the fragments of these works, the fact is that the western and traditional way of thinking of and researching the right, without questioning the relationship articulating "theoretical object" and "empirical object", led the Brazilian constitutionalists to consider the emergence of the Constituent and the Brazilian Constitution out of the context of real political, social, economic and cultural processes of their formation. Thus, the Brazilian Constitution was approached both by Sarmento and Barroso as a rhetorical product of reasoning driven by practical concerns regarding conflict resolution by the judiciary. Ultimately, the current stage of the Brazilian constitutionalism ends up being defined by constitutional changes naturalized in the discourse of the constitutionalists. 


\section{REFERECES}

ALEXY, Robert. Teoria dos Direitos Fundamentais. Malheiros: São Paulo, 2011.

BARROSO, Luís Roberto. Interpretação e Aplicação da Constituição. Ed. Saraiva, 2004.

BENJAMIN, W. "Tesis de filosofia de historia". IN El debate de la postmodernidad. Buenos Aires: Punto Sur, 1989.

BONDY, Augusto Salazar. ¿Existe una filosofía de nuestra América? España, Argentina, Colombia: Siglo XXI editores, 1982.

DWORKIN, Ronald. Taking rights seriously. Cambridge, MA: Harvard University Press, 1977. . Law's Empire. Oxford, Hart Publishing. 1998.

GROSFOGUEL, Ramón. Para descolonizar os estudos de economia política e os estudos pós-coloniais; transmodernidade, pensamento de fronteira e colonialidade global. Revista Crítica de Ciências Sociais, n. 80, p 115-147, mar. 2008.

HABERMAS, Jürgen. Direito e democracia; entre facticidade e validade. Tradução de Flávio Beno Siebeneichler. 2. ed. Rio de Janeiro: Tempo Brasileiro, 2003, v. 1.

HOKHEIMER, Max. Teoria Tradicional e Teoria Crítica; os Pensadores. São Paulo: Abril Cultural, 1980.

MARTÍN-BARRETO, Jesús. "Projetos de modernidade na América Latina" IN DOMINGUES, José Maurício, MANEIRO, María (Orgs). América Latina hoje. Rio de Janeiro: Civilização Brasileira, 2006.

MIGNOLO, Walter. Histórias locais/ projetos globais; colonialidade, saberes subalternos e pensamento liminar. Belo Horizonte: UFMG, 2003.

QUIJANO, Aníbal. "Os fantasmas da América Latina”. IN NOVAES, Adauto. Oitos Visões da América Latina. São Paulo: Senac, 2006.

RAWLS, John. Uma Teoria da Justiça. Tradução de Vamireh Chacon. Brasília: UnB, 1976.

ROSENMANN, Marcos Roitman. Pensar América Latina - El desarrollo de la sociologia latino-americano. Buenos Aires: CLACSO, 2008.

SARMENTO, Daniel. A Garantia do Direito à Posse dos Remanescentes de Quilombos Antes da Desapropriação. Parecer a pedido da $6^{\circ}$ Câmara do Ministério Público Federal. Rio de Janeiro, 09 de outubro de 2006. 
------------. Livres e Iguais; estudos de Direito Constitucional. Rio de Janeiro, Editora Lumen Juris, 2009.

SOUZA NETO, Cláudio Pereira de. SARMENTO, Daniel. Direito Constitucional; Teoria, história e métodos de Trabalho. Livraria Virtual da Editora Forum, 2012.

TAYLOR, Charles, et al. Multiculturalismo; examinando a política do reconhecimento. Lisboa: Piaget, 1998.

WOLKMER, Antônio Carlos. Constitucionalismo e Direitos Sociais no Brasil. Editora Acadêmica, 1989.

ZEA, Leopoldo. Discurso desde a marginalização e a barbárie. Rio de Janeiro: Garamond, 2005. 